\title{
Under the shadow of the state Media framing of attacks on West Papuan students on Indonesian online media
}

\begin{abstract}
The attack on the West Papua student dormitory in Surabaya, East Java, Indonesia, on 16 August 2019 by the Islamic Defender Fronts (FPI), Communication Forum for Retired Children of the Indonesian Military/ Police (FKPPI) and Pancasila Youth (PP) sharpened Indonesia's crisis with West Papua. The baldly racist attack then ignited repression, as well as demonstrations from West Papuans in various cities. In such a crisis, Indonesian online media does not provide proportional voices from West Papuan society. That adds to a record of how bad the practice of journalism related to West Papua so far appears to be. This study conducted a quantitative framing analysis, examining the number of reports, use of resource persons and the use of framing of crisis in the news, on six Indonesian online media: okezone. com, detik.com, kompas.com, tribunnews.com, cnnindonesia.com and tirto. id in the period of August 16-31, 2019. From the 2,471 news reports, it can be seen that most of the main news sources used by the media are from the government and the apparatus and police. West Papuan society received only scant coverage compared with the range of news of the attacks on West Papua student dormitories and their effects. The dominant crisis frames that appear in the news are the frame of attribution of responsibility and frame of conflict. The frame of human interest, frame of morality and frame of economic take the bottom three positions.
\end{abstract}

Keywords: case studies, conflict reporting, crisis journalism, framing, Indonesia, online media, West Papua

JUSTITO ADIPRASETIO

Universitas Padjadjaran, Bandung, Indonesia

\section{Introduction}

ATACKS on the West Papua student dormitory in Surabaya, East Java, Indonesia, on 16 August 2019 involved groups of people who were partially identified using the Islamic Defender Fronts (FPI) insignia, with the Communication Forum for Retired Children of the Indonesian Military/Police (FKPPI) and Pancasila Youth (PP) and the rest wearing ordinary clothes. The at- 
tacks triggered a conflict not only 'vertically' but also 'horizontally' in various regions (CNNindonesia, 2019; Republika, 2019). The conflict was marked by racism with some of the attackers calling the West Papuans 'dogs', 'pigs' and 'monkeys' and making death threats (Sandikin, 2019). This was compounded by repression by the state police apparatus of the Indonesian People's Front for West Papua (FRI-WP) during a demonstration in Ternate, North Maluku, on 15 August 2019 (CNNindonesia, 2019b). That was as well as an attack on West Papuan students in Malang, East Java, when the (West) Papua Student Alliance, carried out peaceful action to protest against the New York Agreement between the government of Indonesia and the Netherlands on 15 August 1962 related to the transition of power in West Papua (Perwitasari, 2019). The crisis escalated and there were frequent clashes in Manokwari, Merauke, Nabire, Yahukimo, Biak and elsewhere. Officials aggravated the situation by using repressive actions and the government even slowed down internet access in Sorong. The Ministry of Communication and Information also closed social media accounts that they claimed were 'provoking' the situation (Abdi, 2019b). This series of actions and imposition of conditions deepened the wounds of prolonged colonialism by Indonesia against West Papua (Anderson, 2015; Supriatma, 2013). But ironically in a crisis like this, Indonesian mass media would again not take sides with West Papua. As in previous cases, the Indonesian mass media tends to confuse the situation (Remotivi.id, 2014).

In the escalation of the West Papua student dormitory case, many news media in Indonesia reported the crisis with weak verification, and dragged the issue into disinformation narratives (Firman, 2019). detik.com, as an online media outlet with the most audience in Indonesia, even reinforced stigma against the students by giving attributions like 'stubborn' to the title of the article -- before they changed it because of a reprimand from the Independent Journalists Alliance (AJI) (Manan, 2019). Some other media participated in facilitating expressions of hatred and discriminatory calls against West Papuans. The biggest problem would be that these media do not report much of the conflict in terms of the perspective of students or West Papuans. The media tend to use a single narrative, which is taken from the perspective of the Indonesian government, using only news sources that come from the police or other government authorities. The principle of balance to cover both sides let alone showing the truth, as the foundation of journalism ethics, is not a priority and is ignored (Kovach \& Rosenstiel, 2014).

\section{The crisis of Papua in frame}

News about West Papua has always been disproportionate in both Indonesian and international media (Firman, 2019; Tapsell, 2015; Robie, 2013; Utomo, 2015). Understanding it cannot be separated from the internal political conditions related to West Papua as a geographical area, as well as ethnic groups 
and long-term colonialism, accompanied by violence exercised by Indonesia (Lawson, 2017; Elmslie \& Webb-Gannon, 2013; Kirsch, 2010; King, 2004). Systematic exploitation of natural resources, destruction of West Papua's resources and plants, compulsory labour (often without compensation), transmigration schemes, and forced relocation have caused widespread environmental damage to the region, ruining traditional subsistence practices, causing disease, malnutrition, and widespread mortality among West Papuans (Brusndige et al., 2004). Inherently, claims that West Papuans are an ethnic population who are often committing violence or that conflict is the norm for West Papua people are used as a justification for the implementation of provincial militarisation and violence (Kirsch, 2010).

All of this is aggravated by government approval of restrictions on foreign and national mass media reporting about West Papua (Leadbeater, 2008). Reporting in the West Papua region in recent decades has been a risky job (Perrottet \& Robie, 2011). There was a distance between West Papuans and not only non-Papuan Indonesians, but also the media which were mostly centralised in Jakarta (Tapsell, 2017; Tapsell, 2015). Such distancing made the West Papuan 'Indonesianisation' project that was tried for many years seem half-hearted (Gietzelt, 1989).

West Papua is a 'blind spot' for the media, especially for foreign journalists (Robie, 2020; Perrottet \& Robie, 2011; Leadbeater, 2008). In what really started with a conflict of interest around the natural resources owned by West Papua, copper and gold, the government did not want foreign or local journalists to expose the crisis there (Robie, 2012; Robie, 2008; Leith, 2003). Indonesia even banned foreign journalists and media workers from entering West Papua. Only a few journalists managed to enter West Papua, most of them not going through official channels (Robie, 2013). As one diplomat said in Jakarta, 'even Jesus Christ could not get permission to go to West Papua' (West Papua, 2015).

When Indonesian President Joko Widodo on 25 May 2015 stated that he would allow journalists to enter West Papua, a maze-like process was needed to gain access to West Papua (Blades, 2016). Research conducted by AJI shows that only 15 foreign journalists, including two New Zealand radio television crews, were allowed to go to West Papua (Saputri, 2019). Most of them encountered serious obstacles or actual harassment and detention (Chivers, 2017f; Wanimbo, 2017). Local independent journalists who reside in West Papua or become correspondents routinely receive threats from the authorities (Blades, 2016). The military 'secretly, and broadly, is involved in domestic security operations' in West Papua, including closely monitoring the journalists (Supriatma, 2013)

West Papua operates in a subnational authoritarian environment whereby local journalists do not have the freedom to report the news like journalists in other regions in Indonesia. The main factors influencing the mainstream news content 
in the region are the security forces and the central government and local government (Tapsell, 2015). Local and foreign journalists see the military as a major threat to their well-being so that freedom of expression in the region narrows and the existence of Special Autonomy funds causes news to be shaped not by what affects West Papuans, but by what is considered relevant by the government. The reluctance of national governments to allow a free media environment can be explained by fears that it would give voice to pro-independence 'separatists', and Indonesia's 'sovereignty' over the region would be regularly questioned in local and international media (Blades, 2018; Macleod, 2016; Tapsell, 2015). The repression carried out by the Indonesian government means news framing related to West Papua is never balanced.

Limited studies of West Papua, and even fewer discussions on how the West Papua crisis is framed by the Indonesian mass media, so far has focused on the structural problems and socio-cultural aspects of journalism practice in West Papua. By using a framing analysis, we can read the sentiments of Indonesian national media regarding the West Papua issue. In the context of this study, we can determine how online media in Indonesia framed the case of the attack on West Papua student dormitories in Surabaya and various post-attack incidents.

Framing itself is a theory in media analysis which has been widely applied to news related to politics (Iyengar, 1990a; Iyengar, 1990b; Iyengar, 1991; De Vreese, 2004; Becker \& Scheufele, 2011), disasters (Entman, 1991; Merry, 2015; Haider-Markel, Delehanty, \& Beverlin, 2007), racism and sexism (Poindexter, Smith, \& Heider, 2003; Ben-Porath \& Shaker, 2010) and terrorism (Norris, Kern, \& Just, 2003; Papacharissi \& Oliveira, 2008). The study of how Indonesian media framed the attack on the West Papua dormitory in Surabaya and events in various post-attack areas will contribute to the deepening of understanding, to what extent the structural and sociocultural dimensions can mediate messages in Indonesian online media related to the West Papua issue (Shoemaker \& Reese, 2014).

There are two approaches in framing analysis: qualitative and quantitative (Weaver, 2007). Qualitative analysis itself is divided into two: first, by using hermeneutic-qualitative, and second, systematic techniques (D'Angelo \& Kuypers, 2016). Hermeneutic-qualitative procedure itself has weaknesses because many of its studies are arbitrary and unsystematic (Tankard, 2001). A qualitative approach using systematic techniques as exemplified by Dijk (2011) and Pan and Kosicki (1993), analysing in detail, syntactical, thematic, rhetorical, and script structures collided with their limitations in analysing large amounts of data.

Another approach is quantitative which is divided into holistic techniques and device oriented techniques (D'Angelo \& Kuypers, 2016). Device oriented techniques will rely on indicators or frame elements consisting of words (Entman, 1991) or argument structure (McComas \& Shanahan, 1999). This study will use a quantitative approach with holistic techniques, in which analysis of 
media frame coding will refer to the previous studies (Nisbet, Hart, Myers, \& Ellithorpe, 2013). This study will refer to the frames of crisis previously described in the An and Gower (2009) study. In crisis situations such as the attack on the West Papua dormitory and various post-attack incidents, the public will seek information about the crisis and try to evaluate the event and find who is most responsible for the crisis (An \& Gower, 1993).

Analysing the news of the attack on the West Papua dormitory and various post-attack incidents, we can see how the Indonesian media choose what they show, and what they remove from the story, as well as who they use as sources in their news, and who or what they do not show (Iyengar \& Kinder, 1987; Pan \& Kosicki, 1993). This study, using quantitative framing analysis, will examine framing conducted by six national online media which are dominant in Indonesia and have the most audience: okezone.com, detik.com, kompas.com, tribunnews. com, cnnindonesia.com and tirto.id. Below are the research questions in this study:

a. How many news items related to the attack on the West Papua dormitory and its escalation?

b. Who are the sources of news in the media regarding the attack on the West Papua dormitory and its escalation?

c. What is the crisis frame that is used in the news regarding the attack on the West Papua dormitory and its escalation?

\section{Methodology}

This study uses a quantitative framing approach with holistic techniques, with the following variables:

\section{Operational variables}

\section{News sources}

Framing is the result of how news sources frame an issue where journalists and news organisations adapt to the frame, renegotiate it, or reframe it based on logic and from the genre of news that will be displayed (De Vreese, 2004)

In this study, the examination establishes the proportion of reportage that comes from various government agencies as news sources, in the news related to the attack on the West Papua dormitory and various escalating events, after the attack.

\section{Crisis frame}

An and Gower (2009) show what frames are contained in the news, and used by newspapers, in news from national media about crisis communication throughout 2006. Previously, some literature had discussed the usual frames used in the news. Neuman, Just and Crigler (1992) discuss comprehensively several types of frames that are dominantly used in newspaper news in the United States: conflict, economic consequences, human impact and mortality. Semetko and Valkenburg 
(2000) research identified five dominant news frames: attribution of responsibility, conflict, economic consequences, human interest, in five types of national newspapers and television news during the Dutch presidency of the European Council in 1997. Meanwhile, an An and Gower (2009) study adopted five frames that had previously been identified by Semetko and Valkenburg (2000).

This study will examine the use of a dominant frame in reporting on the West Papua dormitory attack and subsequent incidents, and how the use of these frames may have influenced the news audience. Crisis frame categorisation will use typology frames that are also used by An and Gower (2009) to analyse crises.

\section{Frame of human interest}

This frame focuses on the face and emotional side of human beings towards an event, issue and problem (Semetko \& Valkenburg, 2000). In a crisis situation, this frame considers psychological influence on humans, which directs the reader or audience to show various negative behaviors in a crisis (Padin, 2005). Cho and Gower (2006) show that with this frame, the emotional response of the reader is affected, which influences how the reader determines who is guilty and responsible in a crisis situation.

\section{Frame of conflict}

This frame is used to show conflict and disagreement between individuals, groups or organisations. Neuman et al. (1992) show that conflict is often used by US news media. Based on the study of Semetko and Valkenburg (2000), this frame is the second most used in news.

\section{Frame of morality}

This frame places events, problems or issues within the scope of moral, social prescription, and religious teachings. Neuman et al. (1992) show that moral frames are generally used by journalists indirectly through quotations or inferences, rather than directly because of the various objectivities attached to journalism activities.

\section{Frame of economy}

This frame reports an event, problem or issue related to its economic consequences on an individual, group, organisation or country. Neuman et al. (1992) identify it as a general framework in news. The large impact of an event is an important news value, and economic consequences are often considered large (Graber \& Dunaway, 2018).

\section{Frame of attribution of responsibility}

This frame is defined as 'a way to connect responsibility for finding solutions or solving problems, both to the government or to individuals or groups' (Semetko \& Valkenburg, 2000). Semetko and Valkenburg (2000) identified that this frame is the most commonly used in serious newspapers. 
The existence of each frame in the news will be measured on a nominal scale of 1 (any) or 0 (none).

\section{Population: Corpus of News}

Corpus of news which becomes the population of this research is all news related to the attack on West Papua student dormitories in Surabaya and riot as the effect of attacks, in six Indonesian online media: okezone.com, detik.com, kompas.com, tribunnews.com, cnnindonesia. com and tirto.id from August 1631, 2019 totalled 2,417 news items.

The data collection process is done by two methods: using the octoparse application and manually, by following each time-based report made when the conflict was still ongoing. After that, the two results will be synchronised to reduce the risk of omitting news coverage not summarised.

\section{Coding procedures}

In performing a reliability test, the researcher used two intercoders (with the person who did the coding to determine reliability of the test results). Each coder coded all articles independently.

Two intercoders, with a sample of $5 \%$ of the entire unit of analysis $(\mathrm{n}=$ 2471), i.e. 124 (with rounding) performed reliability tests. Research reliability test analysis used Krippendorff's alpha $(\alpha)$ process because of its more flexible characteristic. Krippendorff's alpha $(\alpha)$ can account for chance agreement, different levels of coding (i.e. nominal, ordinal, interval, and ratio), multiple coding categories, different sample sizes, and missing data (Klaus. Krippendorff, 2005). The minimum limit of Krippendorff's alpha to be said to be reliable is 0.7000 in $q=0.0125$. (Hayes \& Krippendorff, 2007; Krippendorff, 2011)

The reliability calculation using the SPSS application program version 25, shows the Krippendorff's alpha for the Crisis Frames variable is 0.7835 . Based on the results of the reliability test, it can be concluded the coding process of this study is reliable.

\section{Discussion}

Post-event news in online media

On the first day the West Papua Student dormitory in Surabaya (16/8) was visited by the Indonesian military TNI, followed by the Satpol PP municipal police and Community Organisations, accompanied by a curse: 'Hey dogs, pigs, monkeys, do come out. If you dare, face us in the front.' The news coverage of that event is very minimal (Abdi, 2019a). There were only 16 reports on the first day of the attack which was accompanied by stone throwing and siege. Even when 42 people who remained in the West Papua dormitory the next day were arrested by the police (17/8), there was still very little news reporting. For two 


\section{Graph 1: Papuan dormitory attack news items}

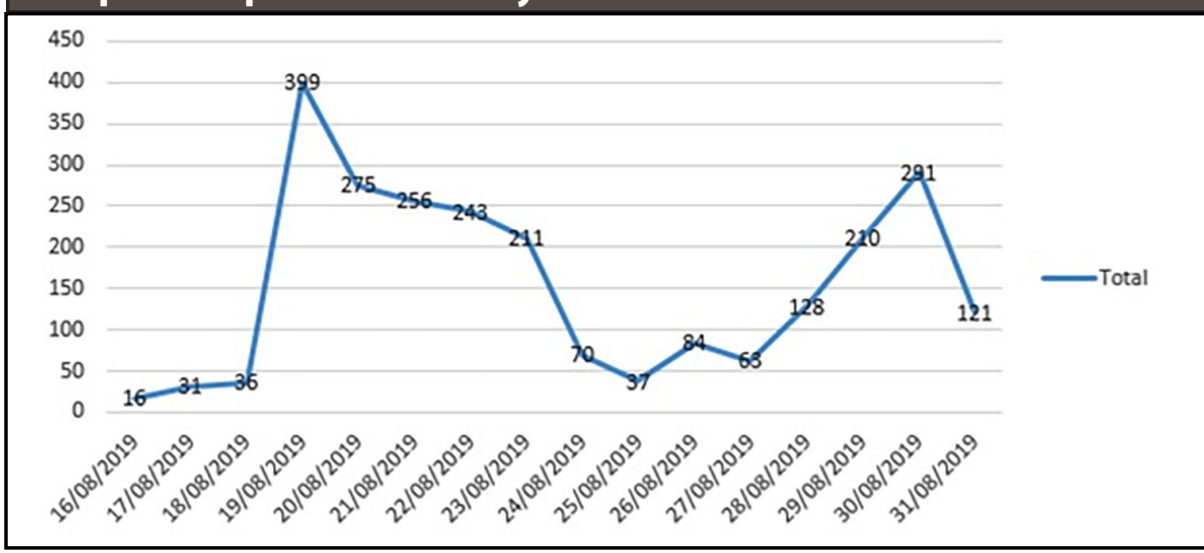

Note: The number of news items related to the attack on the Papuan dormitory in Indonesian online media, 2019.

consecutive days, on August 17, there were only 31 reports related to the attack on the West Papuan dormitory, and on August 18 it only increased to 36 reports (Graph 1).

The day before (15/8) there was an attack on West Papuan students in Malang when the West Papua Student Alliance held a peaceful action to denounce the signing of the New York Agreement. The New York Agreement is an agreement signed by the Netherlands and Indonesia in 1962, regarding the administration of what was then Dutch New Guinea and allowing Indonesian occupation and administration of the territory. The implementation of the New York Agreement completed the early Indonesian nationalist goal of what Sukarno (first Indonesia President) called a 'Republic of Indonesia from Sabang to Merauke' (Adam \& Anwar, 2005).

As a result of the attack, 23 West Papuan students were injured, but on that day there were no media dedicated to reporting the incident. The attack in Malang only appeared a few days later as a part of the narrative chronology of the attack on West Papuan students and the ensuing chaos in Sorong, Manokwari and Fakfak (West Papua).

News rose on 19 August 2019 when protests were held in various areas in West Papua: Manokwari, Sorong and Fakfak. Tense situations as a result of the protests due to racism and persecution had many roads in Manokwari blocked and even the provincial building of the Democratic Party (DPRD) was set on fire. A riot also occurred in Sorong where Domine Eduard Osok Airport was targeted by the masses, pelting the facilities at the airport, while in Fak-Fak, mobs burned stalls at the Fakfak Market and blocked the road to get there.

This was compounded by attacks on a West Papua student dormitory in Makassar, which was visited by around 20 people who were suspected of being members of community organisations. The attack was carried out by using stones 
and arrows. The action was then ended with the presence of the South Sulawesi Police Chief and the South Sulawesi Governor who guaranteed the safety of West Papuan students (Bernie, 2019).

The riot that had not subsided for several days in West Papua became highlighted by the media. On August 19, it peaked as news related to the attack and the effects of the attack on the West Papua student dormitory, with 399 news items per day. Recorded on August 19-23, news related to the attack on the Surabaya West Papua dormitories and the effects of the attacks, were always above 200 news items per day overall across the online media.

After August 23, news about the protests related to West Papuans slowly declined and climbed again starting from August 28 with 128 reports, August 29 with 210 reports and the peak was on August 30 with 291 reports. This was caused by a shooting in Waghete II, Tigi, Deiyai, West Papua on Wednesday (28/8) which then sparked anger among society. The accumulation of anger caused many demonstrations involving thousands to take place in the city of Jayapura for three days (August 29-31, 2019). The demonstrations led to the destruction of buildings at a number of points, one them being the office of the Papua People's Assembly (MRP).

detik.com was the most dominant online media outlet reporting information about the attack on the West Papua Student dormitory in Surabaya, East Java on 16 August 2019 by groups of people who were partially identified using the Islamic Defenders Front (FPI), Pemuda Pancasila (PP) logos, and casual clothing. It covered various situations and conditions after the attack. detik.com produced 613 news reports, followed by kompas.com with 575 news, tribunnews.com with 431 news, cnnindonesia.com with 401 news, then tirto.id with 234 news and okezone.com with 217 news.

All online media provided a large portion of straight news, and only 29 out of 2,471 ( $<1$ percent) of all reports were feature articles (Graph 1). tirto.id was the online media with the highest number of features at the same time, where 8 out of 234 reports ( 3.5 percent) were dedicated to narrative depiction. cnnindonesia.com is the media outlet with the least number of features: one feature from 401 items ( 0.2 percent).

News related to the attack and the aftermath had many failings. Information would become partial, journalism principles such as balance and covering both sides did not become the basis of the news. Things that mattered were speed and quantity, putting aside ethical elements in journalism. This was also manifested in the choice of news sources.

\section{News sources used in the attack on the West Papua student dormitory}

In total, there were 3,100 news sources in 2,471 reports, where the average number of informants was 1.25 news sources per report. Based on this average, the 


\begin{tabular}{|l|c|c|}
\hline \multirow{2}{*}{ Table 1: Papuan dormitory attack news item categories } \\
\hline \multirow{2}{*}{ Online Media } & \multicolumn{2}{|c|}{ News Form } \\
\cline { 2 - 3 } & Straight News & Feature News \\
\hline okezone.com & 212 & 5 \\
\hline tribunnews.com & 424 & 7 \\
\hline detik.com & 610 & 3 \\
\hline cnnindonesia.com & 400 & 1 \\
\hline kompas.com & 570 & 5 \\
\hline tirto.id & 226 & 8 \\
\hline Total & 2442 & 29 \\
\hline
\end{tabular}

Note: The category of news forms related to the attack on the Papuan dormitory in Indonesian online media

majority of news stories only had one source (Table 1). This showed the majority of news would not be balanced over the quantity of news sources in each report.

The majority of the news sources came from state apparatuses: Government and Apparatus / Politicians. 1,191 speakers came from government elements: President, Ministers, Regional Heads, Deputy Regional Heads, Office Heads, etc. Also, 879 speakers came from the police apparatus. The average government or apparatus presence as a news source was 0.83 times an item $(n=2,471)$, or in other words, there was almost always a government or apparatus voice in every news report related to the attack on the West Papua student dormitory.

Against that, there were only 294 news sources from the West Papuan community (Table 2 ), or about 0.12 times per report $(n=2,471)$. For every 10 news reports, only one story presented speakers from the West Papuan community. There were 42 representation of news sources who were part of those who supported 'separatism'/independence in West Papua or were associated with the Free Papua Organisation (OPM). The number of news sources coming from the West Papuan community and those who wanted West Papua to be independent was 336 resource representatives, or 0.14 times per report $(n=2,471)$. This shows that the media in Indonesia, according to the data produced in this study, did not place victims or those who had West Papuan ethnic identity as major voices in the overall news.

Academic narratives only provided minimal reporting about the attack on the West Papua student dormitory attacks. Only 80 news sources from academic circles in the 2471 reports $(0.03)$ were available. This finding showed that the issue of West Papua was 'minimal' from an academic perspective (whether science or humanities). The situation worsened where the Indonesian government imposed strict limits on academics, especially those from outside Indonesia, seeking to conduct research in West Papua. West Papua has become quite impervious to academic discourse, not only in scientific publication papers, but also in journalism. 


\section{Table 2: News sources in the Papuan dormitory attack}

\begin{tabular}{|l|c|c|c|c|c|c|c|}
\hline News Source & $\begin{array}{c}\text { ok- } \\
\text { ezone. } \\
\text { com }\end{array}$ & $\begin{array}{c}\text { tribun- } \\
\text { news. } \\
\text { com }\end{array}$ & $\begin{array}{c}\text { detik. } \\
\text { com }\end{array}$ & $\begin{array}{c}\text { cnnin- } \\
\text { donesia. } \\
\text { com }\end{array}$ & $\begin{array}{c}\text { kompas. } \\
\text { com }\end{array}$ & tirto.id & Total \\
\hline Government & 95 & 232 & 315 & 172 & 258 & 119 & 1191 \\
\hline Apparatus/Police & 56 & 170 & 235 & 131 & 218 & 69 & 879 \\
\hline NGO/Activists & 38 & 75 & 66 & 96 & 87 & 83 & 445 \\
\hline West Papuan community & 22 & 47 & 55 & 50 & 79 & 41 & 294 \\
\hline Academics & 9 & 15 & 14 & 12 & 11 & 19 & 80 \\
\hline Media/Press & 6 & 14 & 2 & 17 & 34 & 4 & 77 \\
\hline Indonesian Political Party & 6 & 15 & 13 & 17 & 9 & 6 & 66 \\
\hline Separatist & 2 & 3 & 9 & 18 & 4 & 7 & 23 \\
\hline Assailant & 0 & 4 & 2 & 8 & 5 & 4 & 23 \\
\hline Celebrity & 1 & 4 & 6 & 4 & 4 & 2 & 21 \\
\hline Total & 235 & 575 & 715 & 518 & 706 & 351 & 3100 \\
\hline
\end{tabular}

Note: The number of news sources of the news related to the attack on the Papuan dormitory in Indonesian online media, August 2019.

The perpetrators of the attack became a news source 23 times - from Islamic Defender Fronts (FPI), Communication Forum for Retired Children of the Indonesian Military/Police (FKPPI) and Pancasila Youth (PP). Only okezone.com did not put the perpetrators of the attack as a news source at all.

Online media in Indonesia, which on other issues has a tendency to trivialise (e.g. interview celebrities), even about reporting with a nuance of violence, do not do so in reporting news of the West Papua student dormitory. Online media in Indonesia often makes celebrities their sources for comment on current popular issues (Adiprasetio, 2019; Adiprasetio \& Wibowo, 2019). In the reporting of the attack on West Papua's student dormitory, there were only 21 representations from celebrities.

detik.com (315) is the media outlet that most makes the government a news source, with kompas.com (258) and tribunnews.com (232) making second amd third place, followed by cnn.indonesia.com, tirto.id and okezone.com. In the consecutive percentage, detik.com (44.06 percent) is the online media most displaying representation from the government as news source, okezone.com (40.43 percent), and tribunnews.com (40.35 percent) provide a portion of more than 40 percent of total news sources with government representation as the news source; followed by kompas.com (36.54 percent), tirto.id (34.00 percent) and cnnindonesia.com (33.27 percent).

detik.com (235) places the representation of the apparatus/police as a news source, more than any other media. kompas.com (218) took second place, followed by tribunnews.com (170), cnnindonesia.com (131), tirto.id (69) and okezone.com 
(56). In terms of percentage, detik.com (32.87 percent) still ranked first, followed by kompas.com (30.88 percent), tribunnews.com (29.57 percent), cnnindonesia. com (25.29 percent), okezone.com (23.83 percent) and tirto.id (19.66 percent).

The dominance of the state's narratives is very strong in news related to the West Papua issue. This is indicated by the domination of government and apparatus representation in news about the case of the West Papua student dormitory attack. If accumulated, detik.com put the government and apparatus/police at 76.93 percent of the news, followed by tribunnews.com (69.92 percent), kompas. com (67.62 percent), okezone.com 64.26 (percent). Only two media outlets gave government and apparatus representation below 60 percent: cnnindonesia.com with 58.49 percent and tirto.id by 53.56 percent.

cnnindonesia.com and tirto.id, which in percentage terms had the least representation of government and apparatus, place the largest representation of NGOs and activists among others. tirto.id allocated 22.79 percent of its news sources for NGOs and activists, while cnnindonesia.com allocated 17.18 percent; followed by okezone.com (16.17 percent), tribunnews.com (12.35 percent), kompas.com (11.19 percent) and detik.com (8.9 percent) with the least percentage.

tirto.id is a media outlet which in percentage gives space for academics, the largest in its news. tirto.id put 5.41 percent of the news source from academics, in second place was okezone.com, 3.83 percent. Other media only placed academics under 3 percent of the total coverage: tribunnews.com (2.61 percent), cnnindonesia.com (2.32 percent), detik.com (1.96 percent) and kompas.com (1.56 percent).

Only two media services put the representation of the West Papua community at more than 10 percent of their total news source: tirto.id (11.68 percent) and kompas.com (11.19 percent). Other online media put the representation of the West Papuan community at less than 10 percent of their total news sourcing: cnnindonesia.com (9.65 percent), okezone.com (9.36 percent), tribunnews.com (8.17 percent) and detik.com (7.69 percent).

Every online media provided space for the Free Papua Organisation (OPM), a pro-independence group fighting for a 'free' West Papua, although it is small. cnnindonesia.com provides 3.47 percent of news sources coming from separatist groups, followed by tirto.id (1.99 percent), detik.com (1.26 percent), okezone.com ( 0.85 percent), kompas.com ( 0.57 percent) and tribunnews.com ( 0.52 percent).

\section{Crisis frame}

Public perception is very dependent on what information or features stand out in their environment (Poindexter et al., 2003). By aligning the data and narrative that is included and what is removed from the narrative of an event, news media frame their own story of the event (S; Iyengar \& Kinder, 1987; Pan \& Kosicki, 1993). The media creates questions in public interpretations of the story (Hallahan, 1999). The 


\begin{tabular}{|l|c|c|}
\hline \multicolumn{3}{|c|}{ Table 3: Papuan dormitory attack news crisis frame } \\
\hline Types of crisis frame & Total & Percentage \\
\hline Human interest & 156 & 6.31 \\
\hline Conflict & 858 & 34.72 \\
\hline Morality & 94 & 3.80 \\
\hline Economic & 103 & 4.16 \\
\hline Attribution of responsibility & 1260 & 50.99 \\
\hline Total & 2471 & 100 \\
\hline
\end{tabular}

Note: The crisis frame of the news related to the attack on the Papuan dormitory in Indonesian online media.

following are the most dominant instances, in framing of crises, in the reporting of the West Papua dormitory attack and various post-assault events.

In the case of news related to the attack on the West Papua dormitory (Table 3), the attribution of responsibility became the most dominant framing of reporting, and took first place with 1,260 (50.99 percent), followed by a frame of conflict with 858 (34.72 percent), frame of human interest with 156 (6.31 percent), frame of economic with 103 (4.16 percent) and frame of morality with 94 (3.80 percent). The findings of this study are somewhat different from previous studies - the study of An and Gower (2009) and Semetko \& Valkenburg (2000) - in that conflict framing is usually dominated by two things: frame of attribution of responsibility and frame of economic, then followed by frame of conflict, human interest and morality.

tirto.id is the only media that provides a portion to the frame of morality of more than ten percent, which is 11.97 percent of the total news (Table 4). This number is far above other outlets, and even doubled compared to second place cnnindonesia.com (4.99 percent). tribunnews.com is an online media service which in percentage gives the biggest portion to the frame of human interest, which is 10.90 percent, above the second place, kompas.com, 8.35 percent. Only detik.com gives a portion of more than five percent for the frame of economic (6.20 percent), the rest giving a portion of under five percent. As for the frame of conflict, cnnindonesia.com is the media that gives the biggest portion 46.38 percent, followed by detik.com (36.87 percent). Attribution of responsibility is the most dominant frame used by all media. However, cnnindonesia.com is the only medium that provides space for a frame of responsibility of under 40 percent, which is 38.90 percent. The most dominant medium in using the frame of attribution of responsibility is okezone.com with (63.59 percent).

\section{Conclusion}

Based on daily news data, it can be concluded that the news related to the attack on the West Papua student dormitory and its effect increases decisively when 


\section{Table 4: The Papuan dormitory attack crisis frames}

\begin{tabular}{|l|c|c|c|c|c|c|c|}
\hline Types of crisis frame & $\begin{array}{c}\text { okezone. } \\
\text { com }\end{array}$ & $\begin{array}{c}\text { tribun- } \\
\text { news.com }\end{array}$ & $\begin{array}{c}\text { detik. } \\
\text { com }\end{array}$ & $\begin{array}{c}\text { cnnindo- } \\
\text { nesia.com }\end{array}$ & $\begin{array}{c}\text { kompas. } \\
\text { com }\end{array}$ & tirto.id & Total \\
\hline Human interest & 1.84 & 10.90 & 2.77 & 5.49 & 8.35 & 7.69 & 6.31 \\
\hline Conflict & 30.41 & 27.15 & 36.87 & 46.38 & 34.78 & 26.92 & 34.72 \\
\hline Morality & 0.00 & 4.41 & 0.16 & 4.99 & 4.52 & 11.97 & 3.80 \\
\hline Economic & 4.15 & 2.78 & 6.20 & 4.24 & 4.17 & 1.28 & 4.17 \\
\hline $\begin{array}{l}\text { Attribution of } \\
\text { responsibility }\end{array}$ & 63.59 & 54.76 & 54.00 & 38.90 & 48.17 & 52.14 & 50.99 \\
\hline Percentage & 100 & 100 & 100 & 100 & 100 & 100 & 100 \\
\hline
\end{tabular}

Note: The proportion of crisis frames of the news related to the attack on the Papuan dormitory in Indonesian online media.

West Papuans protest and the situation leads to riots. Whereas in the early days of the attack on the dormitory, the curve did not climb. After the rioting ended, data for the period August 24-27 showed that coverage did not exceed 90 daily news items per day.

A register of news sources from the government and apparatus/police showed that the narrative of Indonesia's state apparatuses was very strong in reporting related attacks on the West Papua student dormitory, and far outperformed the narratives of elements of West Papuan society. This makes the narrative related to legal and political demands regarding the attack on West Papua's dormitory, only occupy a secondary position, rather than the narrative of security by the state. tirto.id is the media that places the most representations of elements of West Papuan society and victims of attack, which is 22.79 percent of the news sources coming from NGOs and activists who are opposition to the state, and elements of West Papuan society itself as much as 11.68 percent.

When reporting on a crisis, the media tends to point responsibility for the crisis to one party or the other (Semetko \& Valkenburg, 2000). In particular, that happens within the scope of a crisis that can be prevented, such as mistakes where the crisis can occur, notably mistakes that trigger the crisis itself. In this context, the news media will tend to focus on a frame of attribution of responsibility in a crisis, where it is assumed that there is strong and intentional control on the part of the actor.

The frame of conflict is the second type of framing that is most commonly used in reporting attacks on the West Papua student dormitory. This is in line with the study of Semetko and Valkenburg (2000) that found the frame of conflict is the second framework most often used in crisis-related reporting. This frame identifies representations where the media seek to show contestation at various levels of groups, communities, ethnicities and even countries.

On the issue of attacks on West Papuan students and their effects, the protests and riots, the layer of discourse related to its economy ranks fifth in the crisis 
frame. Even though in reality, there is a very significant economic imbalance between West Papua and other regions in Indonesia, especially Java (where the capital and central development are located); restrictions on media access and restrictions on news related to economic issues in West Papua make the economic frame become less prominent in this case, of violence and racism. That might well apply to any news framing in West Papua.

The frame of human interest and frame of morality are not often used in reporting about the attack on the West Papua student dormitory overall. The frame of human interest is used in news narration about victims and those affected. Whereas, the frame of morality is used more often in preventable crises, which assumes a high level of control and intentionality. If the media emphasises the moral and ethical aspects of a crisis, that tends to affect the moral assessment of the community against various parties. In the case of the attack on the West Papua student dormitory and its effects, such coverage partly led to the formation of a bad public moral perception of the government, mass organisations and officials (TNI and police). However, media attention related to the protests of West Papuans, leading to riots in several areas in West Papua, have contributed to the formation of a bad moral perception of the Indonesian people as a whole towards West Papuans.

This framing study has identified characteristics of the coverage of the West Papuan dormitory issue by leading online media outlets in Indonesia, which are overall prejudicial to West Papuan interests. News of the attacks on the dormitory by groups hostile to West Papuans, was given low prominence while news of subsequent rioting by West Papuans was given high prominence. Government agencies were prominent in sourcing, while West Papuan soures, or independent sources received much less access. That contributed to an allocation of blame on West Papuans. The coverage focused on conflict as a framing value. It gave little attention to any economic implications of the crisis, neglecting the deployment of a human interest frame that might have focused on victims of the violence. Also, while not notably interested in morality, the coverage would have contributed to bad relations through stimulating a negative view of West Papuans across Indonesia. 


\section{References}

Abdi, A. P. (2019a). Kisah penangkapan 42 orang di asrama Papua Surabaya versi mahasiswa. Tirto.id. Retrieved June 3, 2020, from https://tirto.id/kisah-penangkapan42-orang-di-asrama-papua-surabaya-versi-mahasiswa-eguq

Abdi, A. P. (2019b). Kominfo perlambat internet di Papua: Buruk \& picu konflik berlanjut. Tirto.id. Retrieved February 12, 2020, from https://tirto.id/kominfo-perlambat-internetdi-papua-buruk-picu-konflik-berlanjut-egJo

Adam, A. W., \& Anwar, D. F. (2005). Violent internal conflicts in Asia Pacific: Histories, political economies, and policies. Jakarta, Indonesia: Yayasan Obor.

Adiprasetio, J. (2019). Kekalahan jurnalisme di hadapan pasar dan pemasaran daring. In Suryana, A. et al. (Eds.), Eksistensi promosi di era digital (pp. 9-21). Bandung, Indonesia: Bitread.

Adiprasetio, J., \& Wibowo, K. A. (2019). A: jurnalisme banal dan trivialisasi. In Media dan pembangunan berkelanjutan: Meneropong peran media massa dalam menunjang SDGs (pp. 1-22). Bandung, Indonesia: Bitread.

An, S.-K., \& Gower, K. K. (2009). How do the news media frame crises? A content analysis of crisis news coverage. Public Relations Review Public Relations Review, 35(2), 107-112.

Anderson, K. (2015). Colonialism and cold genocide: The case of West Papua. Genocide Studies and Prevention: An International Journal, 9(2), 9-25. https://doi. org/10.5038/1911-9933.9.2.1270

Becker, A. B., \& Scheufele, D. A. (2011). New voters, new outlook? Predispositions,social networks, and the changing politics of gay civil rights. Socisciequar Social Science Quarterly, 92(2), 324-345.

Ben-Porath, E. N., \& Shaker, L. K. (2010). News images, race, and attribution in the wake of hurricane Katrina. Journal of Communication, 60(3), 466-490.

Bernie, M. (2019). Kronologi penyerangan asrama Papua di Makassar versi mahasiswa. Tirto.id. Retrieved June 3, 2020, from https://tirto.id/kronologi-penyerangan-asramapapua-di-makassar-versi-mahasiswa-egAJ

Blades, J. (2016). Watching this space, West Papua. Pacific Journalism Review, 22(1), 13-24. https://doi.org/10.24135/pjr.v22i1.10

Blades, J. (2018). Internationalisation of the 'hidden' West Papua issue. Pacific Journalism Review, 24(2), 33-41.

Brundige, E., King, W., Vahali, P., Vladeck, S., \& Yuan, X. (2004). Indonesian human rights abuses in West Papua: Application of the law of genocide to the history of Indonesian control.

Chivers, D. (2017). Morning star rising: Is West Papua freedom really in sight? New Internationalist, (West Papua Special Report: Why the world's forgotten occupation needs you).

Cho, S. H., \& Gower, K. K. (2006). Framing effect on the publics response to crisis: Human interest frame and crisis type influencing responsibility and blame. Public Relations Review, 32(4), 420-422.

CNNindonesia. (2019a). Asrama Papua di Surabaya digeruduk massa beratribut FPI. Retrieved February 12, 2020, from https://www.cnnindonesia.com/nasional/20190816181952-20-422091/asrama-papua-di-surabaya-digeruduk-massaberatribut-fpi

CNNindonesia. (2019b). Kronik rusuh Papua, dari malang menjalar hingga Makassar. Retrieved from https://www.cnnindonesia.com/nasional/20190819200236-20-422845/ kronik-rusuh-papua-dari-malang-menjalar-hingga-makassar 
D’Angelo, P., \& Kuypers, J. A. (2016). Doing news framing analysis : empirical and theoretical perspectives. II II. Retrieved from https://nls.ldls.org.uk/welcome. html?ark:/81055/vdc 100058681739.0x000001

De Vreese, C. H. (2004). Political campaigning in referendums : Framing the referendum issue. Retrieved from http://www.myilibrary.com? id=5503

Dijk, T. A. van. (2011). News analysis : case studies of international and national news in the press. New York, NY: Routledge.

Elmslie, J., \& Webb-Gannon, C. (2013). A slow-motion genocide: Indonesian rule in West Papua. Griffith Journal of Law \& Human Dignity, 1(2), 142-166.

Entman, R. M. (1991). Symposium framing US coverage of international news: Contrasts in narratives of the KAL and Iran air incidents. JCOM Journal of Communication, 41(4), 6-27.

Firman, T. (2019). Media dan diskriminasi rasial terhadap Papua. Retrieved from http:// www.remotivi.or.id/amatan/543/media-dan-diskriminasi-rasial-terhadap-papua

Gietzelt, D. (1989). The Indonesianization of West Papua. Oceania, 59(3), 201-221.

Graber, D. ., \& Dunaway, J. (2018). Mass media and American politics. Thousand Oaks, CA: California CQ Press.

Haider-Markel, D. P., Delehanty, W., \& Beverlin, M. (2007). Media framing and racial attitudes in the aftermath of Katrina. PSJ Policy Studies Journal, 35(4), 587-605.

Hallahan, K. (1999). Seven models of frame: Implications for public relations. Public Relations Research, 11, 113-125.

Hayes, A. F., \& Krippendorff, K. (2007). Answering the call for a standard reliability measure for coding data. Communication Methods and Measures, 1(1), 77-89.

Iyengar, S; \& Kinder, D. R. (1987). News that matters: Television and American opinion. Chicago, IL: University of Chicago Press.

Iyengar, S. (1990). The accessibility bias in politics : television news and public opinion. International Journal of Public Opinion Research., 2(1).

Iyengar, S. (1991). Is anyone responsible? : how television frames political issues. Chicago, IL; London, UK: The University of Chicago Press.

Iyengar, S. (1990). Framing responsibility for political issues: The case of poverty. Polit Behav Political Behavior, 12(1), 19-40.

King, P. (2004). West Papua and Indonesia since Suharto: Independence, autonomy or chaos? Sydney, NSW: University of New South Wales Press.

Kirsch, S. (2010). Etnographic representation and the politics of violence in West Papua. Critique of Anthropology, 30(1), 3-22.

Kovach, B., \& Rosenstiel, T. (2014). The elements of journalism. New York, NY: The Rivers Press.

Krippendorff, K. (2011). Agreement and information in the reliability of coding. Communication Methods and Measures, 5(2), 93-112.

Krippendorff, Klaus. (2005). Content analysis : an introduction to its methodology. Thousand Oaks, CA; London, UK; New Delhi, India: Sage.

Lawson, S. (2017). Regionalism and colonialism in contemporary Oceania. The Round Table: The Commonwealth Journal of International Affairs, 106(2), 143-153. https:// doi.org/10.1080/00358533.2017.1296710

Leadbeater, M. (2008). Media blind spot over West Papua. Pacific Journalism Review, 5(1), 168-175. https://doi.org/https://doi.org/10.24135/pjr.v14i1.932

Leith, D. (2003). The politics of power: Freeport in Suharto's Indonesia. Honolulu, HA: University of Hawai'i Press.

Macleod, J. (2016). Citizen media and civil resistance in West Papua. Pacific Journalism 
Review, 22(1), 38-51. https://doi.org/10.24135/pjr.v22i1.8

Manan, A. (2019). AJI: Terapkan jurnalisme damai dalam peristiwa Papua. Alliance of Independent Journalists (AJI). Retrieved December 12, 2019, from https://www.aji.or.id/ $\mathrm{read} /$ press-release/970/aji-terapkan-jurnalisme-damai-dalam-peristiwa-papua.html

McComas, K., \& Shanahan, J. (1999). Telling stories about global climate change: Measuring the impact of narratives on issue cycles. Communication Research, 26(1), 30-57. https://doi.org/10.1177/009365099026001003

Merry, M. K. (2015). Framing environmental disaster. [Place of publication not identified]: Routledge.

Neuman, R. W., Just, M. R., \& Crigler, A. N. (1992). Common knowledge: News and the construction of political meaning. Chicago, IL: University of Chicago Press.

Nisbet, E. C., Hart, P. S., Myers, T., \& Ellithorpe, M. (2013). Attitude change in competitive framing environments? Open-/closed-mindedness, framing effects, and climate change. JCOM Journal of Communication, 63(4), 766-785.

Norris, P., Kern, M., \& Just, M. R. (2003). Framing terrorism : understanding terrorist threats and mass media. New York, NY; London: Routledge.

Padin, J. (2005). Don't exaggerate bad news. USA Today, p. 11A.

Pan, Z., \& Kosicki, G. (1993). Framing analysis: An approach to news discourse. Political Comm. Political Communication, 10(1), 55-75.

Papacharissi, Z., \& Oliveira, M. de F. (2008). News frames terrorism a comparative analysis of frames employed in terrorism coverage in US and UK newspapers. The International Journal of Press, Politics, 13.

Perrottet, A., \& Robie, D. (2011). Pacific media freedom 2011: A status report. Pacific Journalism Review, 17(2), 148-187. https://doi.org/10.24135/pjr.v17i2.356

Perwitasari, N. H. (2019). Wakil wali kota malang pastikan tak ada pemulangan mahasiswa Papua. Tirto.id. Retrieved February 12, 2020, from https://irto.id/wakil-walikota-malang-pastikan-tak-ada-pemulangan-mahasiswa-papua-egEv

Poindexter, P. M., Smith, L., \& Heider, D. (2003). Race and ethnicity in local television news: Framing, story assignments, and source selections. Journal of Broadcasting \& Electronic Media, 47(4), 524-536.

Remotivi.id. (2014). Andreas Harsono: Tak ada jurnalisme independen di Papua. Retrieved February 12, 2020, from http://www.remotivi.or.id/wawancara/96/AndreasHarsono:-Tak-Ada-Jurnalisme-Independen-di-Papua

Republika. (2019). PP, FKPPI dan FPI meminta maaf. Retrieved from https://nasional. republika.co.id/berita/pwkakm415/pp-fkppi-dan-fpi-meminta-maaf

Robie, D. (2008). Frontline reporting, ethos and perception: Media challenges in the South Pacific. Asia Pacific Viewpoint, 49(2), 213-227. https://doi.org/10.1111/j.14678373.2008.00371.x

Robie, D. (2012). Coups, conflicts and human rights: Pacific media paradigms and challenges. Asia Pacific Media Educator, 22(2), 217-229. https://doi. org $/ 10.1177 / 1326365 \times 13498168$

Robie, D. (2013). Conflict reporting in the South Pacific: A critical reflexive approach to Timor-Leste and West Papua. Media Asia, 40(2), 147-161. https://doi.org/10.108 0/01296612.2013.11689963

Robie, D. (2020). Key Melanesian media freedom challenges: Climate crisis, internet freedoms, fake news and West Papua. Pacific Journalism Review : Te Koakoa, 26(1), 15-36. https://doi.org/10.24135/pjr.v26i1.1072

Sandikin, R. A. (2019). Kronologi persekusi mahasiswa Papua, ancaman dibunuh hingga makian rasial. Retrieved February 12, 2020, from https://www.suara.com/ 
news/2019/08/19/130345/kronologi-persekusi-mahasiswa-papua-ancaman-dibunuhhingga-makian-rasial

Saputri, M. (2019). AJI kritik pengusiran 8 jurnalis asing di Jakarta \& Papua. Tirto.id. Retrieved October 13, 2020, from https://tirto.id/aji-kritik-pengusiran-8-jurnalisasing-di-jakarta-papua-coLM

Semetko, H., \& Valkenburg, P. (2000). Framing European politics: a content analysis of press and television news. Journal of Communication, 50(2), 93-103.

Shoemaker, P. J., \& Reese, S. D. (2014). Mediating the message in the 21st century a media sociology perspective. New York \& London: Routledge.

Supriatma, A. M. T. (2013). TNI/POLRI in West Papua: how security reforms work in the conflict region. Indonesia, 95(April), 103.

Tankard, J. (2001). The empirical approach to the study of media framing. In S. Reese, A. Grant, \& O. Gandy Jr (Eds.), Framing public life perspectives on media and our understanding of the social world (pp. 95-106). New York, NY, \& London, UK: Routledge.

Tapsell, R. (2015). The media and subnational authoritarianism in Papua. South East Asia Research, 23(3), 319-334. https://doi.org/10.5367/sear.2015.0274

Tapsell, R. (2017). Media power in Indonesia: Oligarchs, citizens and the digital revolution. London, UK, \& New York, NY: Rowman \& Littlefield Publishers.

Utomo, W. P. (2015). Menyembunyikan Papua. Remotivi.id2. Retrieved February 12, 2020, from http://www.remotivi.or.id/kabar/234/menyembunyikan-papua

Wanimbo, R. (2017). Women are speaking out. New Internationalist, (Special Report: West Papua: Why the world's forgotten occupation needs you.).

West Papua: In need of media coverage and international attention. (2015). Unrepresented Nations \& Peoples Organisation. Retrieved July 2, 2020, from https://unpo. org/article/18808

Justito Adiprasetio is a lecturer in the Department of Journalism, Faculty of Communication, Universitas Padjadjaran, Bandung, Indonesia. He has been teaching contemporary journalism and media studies since 2015. He has authored a book about gender relations and currently is in the process of publishing a book on power relations in the history of communication studies in Indonesia. He researches and regularly writes on journalism in Indonesia in scientific journals and mass media.

justito.adiprasetio@unpad.ac.id 